tential problems to watch for and ways to get help if eating disorders are suspected.

The authors manage to maintain an effective balance between anecdotal stories about women who try to meet expectations of coaches or themselves and have trouble with eating disorders and scientific explanations of the physiology of nutrition, menstruation, and osteoporosis. It is written in a style that should be clear to lay persons. Throughout the book, examples (and photographs) of healthy, fit, active women are used to combat the image of extreme thinness as the ideal body type. There are specific accounts of different body types and how they may be suited for different activities, and there is a strong emphasis on the importance of a positive selfimage regardless of body type. In particular, the practice of weekly weigh-ins or body-fat composition testing are sharply criticized as not having significant validity or predictability with regard to performance.

If there is a fault, it may be the emphasis on the idea that one can eat whatever one wants and not worry about weight as long as one is active and performs well. This may work for committed young athletes who are working out many times a week and competing regularly, but middle-aged adults who are "weekend warriors" and do not train as intensively may need to watch their weight as well as their performance.

In general, this book has a good deal of information and should be a useful resource for athletes, coaches, and families. It is easy reading for lay people, and it should be helpful to medical personnel who work with young athletes.

Susan T. Snider, MD Spruce Pine, NC, USA

\section{A Life on the Edge: Memoirs of Everest and Beyond}

Jim Whittaker

Seattle: The Mountaineers Books 1999

Softcover, \$16.95; 266 Pages

"If you're not living on the edge, you're taking up too much space" is the motto Jim Whittaker claims to have lived his life by, and judging by his memoir (published when he was 70-years old), this is not an idle boast but an apt description of "a life well-lived." For those not familiar with Whittaker and his multitude of accomplishments, this book is a fascinating read, riveting, and inspiring. For those who may know of him, or the lucky ones who know him, it will provide yet more insight into a remarkable and likable man.

The most notable of Whittaker's accomplishments was his 1963 climb of Mount Everest-he was the first American to stand atop the highest point on earth. His other mountaineering achievements include ascents of Denali, being leader of the team to place the first Americans atop K2, and organizing and leading the Mount Everest Earth Day 20 International Peace Climb 1990, which succeeded at the dual laudable goals of hauling tons of trash off the slopes of Mount Everest (before it became fashionable to do so!) and placing climbers from the three "cold-warring" superpowers of the time, the U.S., the Soviet Union, and China, on the summit of Mount Everest in order to demonstrate the ability of the three countries to work as a team.

Whittaker's mountaineering achievements reveal only one facet of his fascinating life, however, and this book reveals many more. As the first employee and eventual CEO of Recreational Equipment, Inc., he built the company from a tiny co-op into a giant multinational retailer. He's been very involved in mountain guiding and rescue, politics and wilderness preservation, open water sailboat racing, and he is the devoted father of 5 boys.

The book is written in an unpretentious and straightforward fashion, a simple chronology of his life. It begins by describing his near idyllic childhood, raised among the mountains of the northwestern U.S. with his twin brother Lou (later became the renowned Mount Rainier guide). Throughout, Whittaker carefully explains his motivations and details the pivotal moments of his life.

What is so engaging about this memoir is its honesty and self-examination. Whittaker has developed substantial insight into his life, and looks back on his mistakes with appropriate contrition, willing to admit his failings and learn from them. There are in fact parts of the book that may certainly offend other players in the drama of his life, but the fact that he admits as many of his own failings makes up for this. For a man of so many accomplishments his humility is refreshing, particularly in our times where boastfulness seems to be in vogue (witness many of the current sports heroes). Not only does he describe the great highs of his life but he also details the lows (his failed marriage, near bankruptcy, and mountaineering failures). As he aptly and touchingly points out, it took more courage to transcend those failures than to achieve his greatest successes.

This is an excellent book by and about a fascinating man, and will please any reader who loves mountains and wilderness the way Whittaker does, or any reader who seeks insight into a life well lived. Buy it or borrow it. But definitely, read it.

Robert S. Hamilton, MD Palo Alto, California 